4. Лапина О. А. Индивидуальность учителя: [учеб. пособие] / О. А. Лапина. Иркутск : Изд-во Иркутс. гос. пед. ун-та, 2006. - 133 с.

5. Митина Л. М.Концепция профессионального долголетия / Л. М. Митина // Директор школы. - 1998. - № 5. - С. 31-36.

6. Орлов Ю. М. Мышление, дарящее здоровье и успех / Ю. М. Орлов // Воспитание школьников. - 1993. - № 5-6. - С. 3-6.

7. Пил Н. В. Удивительные результаты позитивного мышления / Н.В. Пил. - Мн. : ООО «Попурри», 2003. - 320 с.

8. Савчук Н. А. Психолого-педагогічні умови корекції особистісних дисгармоній вчителів загальноосвітніх шкіл: дис... канд. психол. наук : 19.00.07 / Н. А. Савчук. - К., 2005. - 183 c.

9. Соколовская Л. Б. Актуализация духовно-творческого потенциала личности как чинника психологического здоровья молодого человека: дис... канд. психол. наук: 19.00.01 / Л. Б.Соколовская. - Красноярск, 2004. - 191 с.

10. Субботина И. В. Становление индивидуально-творческого стиля деятельности будущего учителя музыки в педагогической практике: дис. ... канд. пед. наук : 13.00.01 / И. В. Субботина. -Волгоград, 2007. - 176 с.

11. Титаренко Т. М. Життєвий світ особистості: у межах і за межами буденності / Т. М. Титаренко. - К. : Либідь, 2003. - 276 с.

12. Тригранян Р. Я. Стресс и его значение для организма / Р. Я. Тригранян / отв. ред. О. Г. Газенко. - М. : Наука, 1988. - 176 с.

Стаття надійшла до редакції 23.05.2012 p.

УДК 378. 167

3. С. Кучер, кандидат пед. наук, доиент, Криворізький педагогічний інститут ДВНЗ «Криворізький національний університет

\title{
АКТИВІЗАЦІЯ ПІЗНАВАЛЬНОЇ ДІЯЛЬНОСТІ СТУДЕНТІВ ТЕХНОЛОГО-ПЕДАГОГІЧНОГО ФАКУЛЬТЕТУ ЗАСОБАМИ ПРОЕКТУВАННЯ
}

Кучер 3. С. Активізація пізнавальної діяльності студентів технолого-педагогічного факультету засобами проектування.

У статті розкрито особливості активізащіі пізнавальної діяльності студентів із використання навчального проектування. Особливу увагу приділено структурним складникам проектів та обгрунтуванню педагогічних умов організації навчального проектування.

Ключові слова: пізнавальна активність, проект, навчальний проект, педагогічні умови, принципи проектування.

Кучер 3. С. Активизация познавательной деятельности студентов технологопедагогического факультета средствами проектирования.

В статье раскрыто особенности активизации познавательной деятельности студентов c использованием учебного проектирования. Особое внимание уделено структурным составляющим проектов и обоснованию педагогических условий организации учебного проектирования.

Ключевые слова: познавательная активність, проект, учебный проект, педагогические условия, принщипы проектирования.

Kucher Z. Activation of cognitive activity of students techno-pedagogical faculty of design tools.

The article revealed feature senhance the cognitive activity of students with academic planning. Particular attention is paid to the structural components of the projects and the justification of pedagogical conditions of educational design.

Key words: cognitive activity, project, schoolproject, teaching conditions, principles of design. 
Постановка проблеми. Питання активізації пізнавальної діяльності належать до найбільш актуальних проблем сучасної педагогічної науки i практики. Пізнавальну активність можна вважати одним із головних критеріїв якості підготовки студентів, а ефективне ії формування можливо забезпечити за умов спеціальної організації пізнавальної діяльності. Ї̈̈ особлива значущість полягає в тому, що навчання спрямоване не тільки на сприйняття навчального матеріалу, але й на формування позитивного ставлення студентів до пізнавальної діяльності. Перетворювальний характер діяльності завжди пов'язаний з активністю суб'єкта. Знання, отримані в готовому вигляді, як правило, викликають у студентів певні труднощі під час їх застосування або в процесі розв'язання конкретних завдань, що зумовлено формальним вивченням теоретичних положень і невмінням їх застосовувати практично.

Аналіз останніх досліджень і публікацій. Педагогічні основи процесу пізнання в сучасних вищих закладах освіти досліджували українські й російські науковці: А. Алексюк, Ю. Бабанський, В. Давидов, В. Лозова, П. Підкасистий, М. Пістрак; вивченням структури процесу навчання займалися: Т. Ільїна, I. Ільясов, І. Лернер, В. Фоменко, В. Ягупов; умови ефективної організації навчально-пізнавальної діяльності студентської молоді розглядали: П. Автономов, В. Буряк, Л. Петренко, М. Скаткін, А. Сорокін; форми та методи активізації навчально-пізнавальної діяльності знайшли відображення в працях В. Лозової, В. Онищука, І. Харламова та інших.

Проблемі активізації пізнавальної діяльності присвячені дослідження багатьох психологів і педагогів (Л. Аристова, Л. Занков, І. Лернер, П. Підкасистий, М. Скаткін, Т. Шамова, Г. Щукіна та інші). Останній час до методу проектування привернута значна увага науковців та практиків О. Коберника, В. Симоненко, В. Овечкина та інших. Проте активізація пізнавальної діяльності студентів засобами проектування досліджена недостатньо.

Мета статті - висвітлити сутність поняття «активність», виявити види активності, фази навчального проектування, умови активізації пізнавальної діяльності студентів, що сприяють розвитку навчально-пізнавального інтересу, формуванню мотивації навчання.

Виклад основного матеріалу. Активність у наукових дослідженнях трактується як поняття, що охоплює будь-яку діяльність. За основними функціями всі види активності А. Матюшкін умовно розділяє на два крайніх типи: адаптивний і продуктивний. Адаптивні види активності забезпечують пристосування, продуктивні складають основу виникнення та становлення різних психічних новоутворень. На думку автора, у системі пізнавальних інтересів активність $\epsilon$ на трьох рівнях. У продуктивній пізнавальній активності ці рівні виражаються: 1) як активність уваги; 2) як дослідницька пізнавальна активність; 3) як особистісна активність [2, с.5].

Адаптивні форми активності та відповідні їм процеси викликаються чисельними потребами та мотивами досягнення успіху. Виникнення циклу адаптивної активності пов'язано із виникнення, а завершення - 3 iii 
задоволенням. Розвиток адаптивних форм активності та адекватних форм поведінки, діяльності, мислення відбуваються за загальними законами тренування, що включає передовсім охоплює повторення і контроль (оцінку) як необхідні способи дидактичного управління формуванням навичок. Найтиповішою організаційною формою є навчання «за зразком».

Залежно від характеру діяльності, що здійснює студент, ступеню самостійності та творчості більшість науковців, виокремлюють три рівні пізнавальної активності: репродуктивний (нижній рівень якої характеризується пасивністю); реконструктивний (характеризується прагненням удосконалювати певну діяльність); творчий (має вищий рівень інтелектуальної активності, характеризується ініціативою в постановці завдань). Та як зазначає Е. Полат, знання в сучасному світі надають людині можливість зайняти місце у сучасній культурі й цивілізації за умови, якщо вони подані в оцінці сучасного інформаційного суспільства системно, міждисциплінарно та узагальнено [3, с. 87].

С. Дворецький подає проектну культуру студентів у вигляді моделі навчально-інформаційного середовища проектування, в основі якої знаходяться два блоки: структурно-змістовний та організаційно-процесуальний [1, с.18].

Перший, структурно-змістовний блок, спрямований на формування системного підходу до процесу проектування та сприяє оволодінню спеціальними активними методами розв'язання творчих задач (методи інтуїтивного пошуку рішень, метод евристичних прийомів, метод гірлянди випадковостей та асоціацій, мозкової атаки та ін.). Формує необхідні уміння та навички ефективного планування та організації проектної діяльності, самоаналізу і рефлексії, презентації і навичок прийняття рішень.

Організаційно-процесуальний блок сприяє досягненню оптимальних умов активізації навчально-пізнавальної діяльності студентів у процесі оволодіння ними основами проектування.

В енциклопедичному словнику проект визначено декількома значеннями: 1) реалістичний задум, план бажаного; 2) сукупність документів (розрахунків, креслень, макетів) для створення якогось продукту, містить раціональне обгрунтування та конкретний спосіб здійснення; 3) метод навчання, заснований на постановці соціально-значущої мети та ії практичному досягненні [5, с. 1076]. А проектування трактується як дія за одним із значень слова «проект». Слово «проектування», як похідне від слова «проект», означає діяльність, що ініційована проблемою, яка включає чітко впорядковану послідовність дій, що ведуть до реального результату [5, с.1078].

I. Тарасова визначає «проект» як п'ять «П»: 1) проблема; 2) проектування (планування); 3) пошук інформації; 4) продукт; 5) презентація. I шостим «П»це його портфоліо [6, с.26].

Більшість науковців спираються на два значення слова «проект»: 1) проект як результат проектувальної діяльності; 2) проект як форма організації сумісної діяльності людей. 
За словником проектування - це створення нового об'єкту на папері, а конструювання - його створення в матеріалі [5, с.29].

У процесі проектування студент здійснює різні види діяльності: планування, прогнозування, моделювання, конструювання, робота з ідеями та інше, які в свою чергу є складовими процесу проектування.

С. Дворецький розглядає проектування як інтелектуальну діяльність i головним у ній вважає опрацювання, генерацію, комбінування проектних ідей та рішень, що і зумовлює розуміти проектування як постійний процес вибору, процес прийняття рішень, процес розв'язання задач і проблем [1, с.52].

Не існує єдиної позиції щодо класифікації навчальних проектів. Для раціональної організації проектної роботи задля активізації самостійної пізнавальної діяльності студентів, грунтуючись на результатах дослідження I. Тарасової [6, с. 19], нами обрано для реалізації у навчальному процесі такі основні види проектів: за домінуючою діяльністю - практико-орієнтовані, творчі; відповідно до предметно-змістовної області - міжпредметні; за числом учасників - індивідуальні; за часом - короткострокові (4-10 навчальних годин). Впевненості у правильності нашого вибору додає і висновок системи «Міжнародний бакалавріат», що пропонує тільки персональні проекти.

Індивідуальний проект має ряд суттєвих переваг - дає студенту можливість: обрати тему у відповідності з інтересами та індивідуальними особливостями; у процесі проектувальної діяльності формується відчуття особистої відповідальності, самостійної, організованості та ініціативності; здійснювати проектування у власному темпі; сформувати важливі уміння та навички дослідницької, операційної, конструкторської, технологічної та оцінювальної діяльності; сформувати навички самостійної індивідуальної роботи; виявлення та формування основних рис творчої особистості.

Індивідуальний навчальний проект тим відрізняється від групового, що демонструє головний результат роботи над проектом - аналіз діяльності, пред'явлення способів розв'язання проблеми проекту, демонстрування росту своєї компетентності, формування проектної культури.

Навчальні проекти дещо відмінні від проектів виробничих, перш за все масштабністю. Що стосується проектування студентами технолого-педагогічного факультету, необхідно зазначити про їх максимальну наближеність до проектування як процесу створення моделей одягу на підприємстві. Відмінність полягає тільки у ступені самостійності проектування. Навчальний проект можна розглядати як сумісну навчально-пізнавальну, творчу чи ігрову діяльність, що має спільну мету, узгоджені методи, способи діяльності, спрямовані на досягнення спільного результату діяльності.

Н. Пахомова розкриває сутність навчального проекту з двох боків: 3 позиції студента та 3 позиції викладача. Дидактичну ознаку навчального проекту визначає як можливість студенту зробити щось цікаве в групі чи самостійно, максимально використовуючи свої можливості, це діяльність, що дозволяє виявити себе, спробувати власні сили, застосувати знання, принести користь і публічно показати досягнутий результат. Це діяльність, 
що спрямована на розв'язання цікавої проблеми, сформульованої студентом у вигляді мети та задач, коли результат такої діяльності носить практичний характер, має важливе прикладне значення і цікавий для самих розробників. Із позиції викладача, навчальний проект - це дидактичний засіб, що дозволяє навчити проектуванню, тобто навчити цілеспрямованій діяльності знаходження способів розв'язання проблеми шляхом розв'язання задач, зумовлених цією проблемою під час розгляду іiі у певній ситуації [4, с. 16-19].

У визначенні Н. Пахомової, навчальний проект - це одна із особистісно зорієнтованих технологій, спосіб організації самостійної діяльності студентів, спрямований на розв'язання задач навчального процесу, що інтегрує в собі різноманітні підходи та методики: проблемний підхід, групові та індивідуальні методи, рефлексивні, презентативні, дослідницькі, пошукові та інші [4, с.30].

Технологія проектування опирається на певні принципи, норми та правила проектування, що дозволяють організувати діяльність студентів від ідеї до іiі практичного втілення. Особливої уваги заслуговують такі узагальнені принципи:

- принцип особистісного розвитку (передбачає можливість особистісного розвитку, самоконтролю і самореалізації);

- принцип керованості (передбачає чітку організацію, технологічність);

- принцип цілісності (створення умов для виявлення кожним пізнавальної і творчої активності);

- принцип поєднання дослідницької, проектувальної та педагогічної діяльності (С. Палецький - якість дослідницької діяльності у значній мірі визначає якість проекту);

- принцип продуктивності (інтеграція процесів оволодіння та застосування знань у всіх сферах життєдіяльності).

С. Дворецький виокремлює такі етапи проектування: 1) ініціюючий, призначенням якого $є$ формування умінь постановки цілей i задач; 2) основопокладаючий - формування навичок самоаналізу; 3) прагматичний формування навичок оформлення результатів проектування; 4) заключний формування умінь прийняття інноваційних рішень; 5) підсумковий формування умінь архівування. Представляє інтерес трактування автором психологічних особливостей сучасної проектної діяльності студентів, що виявляється у наступному:

- спрямованості кожного етапу проектування на формування мотиваційного, когнітивного, операційного, емоційно-вольового та інформаційного компонента готовності до проектної діяльності;

- виявленні психолого-педагогічних умов активізації навчальнопізнавальної діяльності студентів у відповідності задля та особливостями кожного з етапів проектування;

- визначенні та розробленні комплексу навчально-методичних та програмно-технічних засобів для проектування [1, с.15-17]. 
Необхідно зазначити, що процес навчального проектування можна представити як три сходинки (фази) навчання: 1) підготовка до проектування; 2) осмислення (засвоєння нової інформації); 3) рефлексія (систематизація, оцінка та застосування нових знань та умінь).

Вибір тих чи тих інтерактивних методів визначено конкретною метою, що присутня на кожній фазі. Перша мета фази підготовки - визначення рівня власних знань, що дозволяе студентам встановити, що вони знають із необхідних предметів. Друга - активізація студентів, так як саме активізація мисленнєвої діяльності дає змогу ефективно пов'язати нову інформацію із вже відомою. Третя ціль - формування інтересу до предмету проектування, як умови підтримки активності студента.

На фазі осмислення студенти вступають у контакт із новою інформацією і першою метою цієї фази є підтримка активності та інтересу, сформованого на першій фазі (підготовки), другою - $\epsilon$ підтримка зусиль студентів у формуванні власного розуміння.

На фазі рефлексії студент закріплює нові знання, переглядає попередні уявлення задля включення в них нових понять. Перша мета цієї фази формування умінь та навичок формулювати нові ідеї, бачити реальні шляхи застосування знань на практиці. Безумовно, цьому сприятиме досягнення другої мети - живий обмін ідеями між студентами.

Особливого значення оволодіння методом навчальних проектів набуває для майбутнього вчителя технологій, що вимагає уміння працювати відповідно до ситуації, досконалого оволодіння проектною технологією у різних галузях виробництва, відрізняти навчальний і промисловий проекти. Використання проекту в межах декількох навчальних дисциплін (технологія швейного виробництва, конструювання, матеріалознавство, моделювання, економіка тощо) сприяе активізації пізнавальної діяльності студентів протягом усього періоду навчання, розвиває творче мислення, формує уміння та навички прийняття рішень у нестандартних ситуаціях.

Розвиток пізнавальної продуктивної активності не підпорядковується строгим законам тренування і основу їі розвитку складають стимулювання та заохочення самих процесів пізнавальної активності [3, с.6].

Необхідною навчальною формою розвитку пізнавальної активності А. Матюшкін вважає лабораторні і практичні заняття, саме тут засвоєння наукових знань здійснюється у формі розв'язання життєвих або лабораторно представлених проблем, а процес пізнавальної активності виражений як практичне мислення та дослідження [3, с.164].

Метод навчального проектування дозволяє внести в сучасну технологію навчання два суттєвих доповнення - зміна у функції знань та способів організації процесу їх засвоєння. Процес засвоєння перестав носити характер монотонного заучування й організується у різноманітних формах пошукової, проектної, мисленнєвої діяльності як продуктивний творчий процес. Основою навчального проектування постає засвоєння як знань так і 
способів засвоєння, розвиток та активізація пізнавальних сил i творчого потенціалу студентів.

На підставі наших досліджень можна виокремити деякі умови ефективної організації пізнавальної діяльності студентів у процесі проектування:

1. У сучасному навчальному процесі рекомендувати не готовий матеріал для використання у проектуванні, а тільки приклад, що демонструє певні шляхи досягнення конкретної мети або інформація для роздумів та самостійного пошуку.

2. Формуванню пізнавальної активності сприяє також посилення творчого елементу в навчальній діяльності студентів, забезпечення цікавості у викладанні, вихід за межі програми та ін.

3. Однією з умов активізації пізнавальної діяльності $\epsilon$, безумовно, оцінювання результатів навчального проектування. Особливу увагу приділяємо поетапному оцінюванню, що призводить до якісного кінцевого результату. Майбутньому вчителю необхідно вміти об'єктивно оцінювати рівень навчальних досягнень учнів, тому ми широко використовуємо самоконтроль за розробленими критеріями. Пропонуємо студентам самостійно розробляти критерії оцінювання окремих технологічних операцій.

4. Навчальне проектування вважаємо оптимальною формою організації пізнавального процесу на практикумах із конструювання та пошиття виробів, де студент має змогу проектувати, конструювати та виготовити виріб будьякої складності. Головне у навчальному проектуванні, що $є$ вихід на кінцевий результат, на практичну спрямованість проектної діяльності - все, що проектується можна одягти, продемонструвати. Спираючись на думку науковців, що потреба є джерелом активності, а задоволення одних потреб зумовлює виникнення нових, ми пропонуємо студентам проектувати моделі одягу для подіуму, що стимулює інтерес до проектування, активізує їх пізнавальну діяльність. Стійкі пізнавальні інтереси забезпечують активну діяльність студентів.

Висновки. Констатуємо, що у процесі навчального проектування пізнавальний інтерес вступає в суперечність із запасом знань, що і викликає у студента внутрішню потребу задовольнити інтерес шляхом активізації пізнавальної діяльності.

Міжпредметні зв'язки у навчальному проектуванні мають особливе значення, оскільки студент має застосувати знання із низки дисциплін, що вивчалися раніше: матеріалознавство, конструювання, технологія, моделювання, креслення, обладнання, образотворче мистецтво тощо.

Проектна діяльність активізує розумову діяльність, студент, повертаючись до вже засвоєного раніше, бачить у фактах, явищах, закономірностях щось нове, розглядає, аналізує певні нові сторони, риси, особливості цих фактів і явищ.

Навчальне проектування характерне великою різноманітністю, багатоваріантністю, не повторюваністю. У процесі проектування студент знаходиться у постійному пошуку, навіть незалежно від того, на якому рівні 
пізнавальної активності він перебуває і 3 яким рівнем самостійності здійснюється проектувальна діяльність.

\title{
Література
}

1. Дворецкий С. Формирование проектной культуры / С. Дворецкий // Высшее образование в России, 2003. - №4. - 193 с.

2. Матюшкин А. М. Теоретические исследования. Психологическая структура, динамика и развитие познавательной активности / А. М. Матюшкин. // Вопросы психологии/ [электронный ресурс] адрес http//www.voppsy.ru/issues/1982/824/824005.htm C. 5-17.

3. Новые педагогические и информационные технологии в системе образования: [учебн. пособие для студентов пед. вузов и системы повышения квалификации педагогических кадров] / Е. С.Полат и др. ; под ред Е. Полат. - М.: Издательский центр «Академия», 1999. - 123 с.

4. Пахомова Н. Ю. Учебный проект: его возможности / Н.Ю.Пахомова // Учитель. 2000. - №4. - С. 15-35.

5. Советский энциклопедический словарь. - М. : Советская энциклопедия, 1989. - 1630 с.

6. Тарасова И. П. Метод проектов в образовательном учреждении / И. П.Тарасова // Приложение к журналу «Профессиональное образование», 2004. - №12. - 110 с.

Стаття надійшла до редакції 23.05.2012 p.

\section{КОМПОЗИЦІЯ УКРАЇНСЬКОГО НАРОДНОГО ОДЯГУ ЯК ДЖЕРЕЛО ВИВЧЕННЯ ОСНОВ ЕТНОДИЗАЙНУ}

\author{
етнодизайну. \\ Кучер С. Л. Композиція украӥнського народного одягу як джерело вивчення основ \\ У статті розкрито питання ознайомлення майбутніх учителів технології з особливими
} рисами національного етнодизайну. Одну із сторін етнодизайну, що пов'язана із творенням одягу, пропонується вивчати у три етапи: 1) ознайомлення з композицією національного костюму; 2) виготовлення традиційного вбрання на основі багатовікової технології; 3) трансформачія ідей украӥнського народного одягу в дизайні сучасного вбрання та аксесуарів.

Ключові слова: підготовка учителів технологій, композииія одягу, традиціийий украӥнський костюм, етнодизайн.

Кучер С. Л. Композиция украинской народной одежды как источник изучения основ этнодизайна.

Статья раскрывает вопросы ознакомления будущих учителей технологии с особенными чертами национального етнодизайна. Одну из сторон етнодизайна, связанную с созданием одежды, предлагается изучать в три этапа: 1) ознакомление с композицией национального костюма; 2) изготовление традищионной одежды на основе многовековой технологии; 3) трансформация идей украинской народной одежды в дизайне современного костюма и аксессуаров.

Ключевые слова: подготовка учителей технологий, композиция одежды, традиционный украинский костюм, етнодизайн.

Kucher S. The composition of the Ukrainian national clothes as a source of learning the basics etnodizayna.

The article reveals problems familiarize future teachers with the technology of special features of national design. One of the parties of design based on ethnic associated with the creation of clothing, 